\title{
MODELLING OF A TRANSIENT-TEMPERATURE FIELD IN PLASTICS DURING LASER CUTTING
}

\author{
MODELIRANJE PREHODNEGA TEMPERATURNEGA POLJA V \\ PLASTIKI MED LASERSKIM REZANJEM
}

\author{
Oldřich Šuba, Libuše Sýkorová, Vladimír Pata, Oldřich Šuba jr., Milena Kubišová \\ Tomas Bata University in Zlín, Faculty of Technology, Vavrečkova 275, 76001 Zlín, Czech Republic \\ osuba@ft.utb.cz \\ Prejem rokopisa - received: 2017-06-30; sprejem za objavo - accepted for publication: 2017-10-11
}

doi:10.17222/mit.2017.091

\begin{abstract}
This article deals with the area of non-conventional technologies. It reports, in detail, on a research of a laser beam and its use on different types of polymeric materials. The topic discussed in this article is mainly the thermal transmittance after the transition of the laser beam, cutting the polymeric materials. At a small distance from the cutting edge, various structural and chemical changes can occur due to the heat transfer to the material. An influence zone arises, which can play a significant role affecting the product capabilities. To establish the affected-zone width, models of the transient-temperature field were prepared, representing the distribution of the temperature in the vicinity of the cutting edge. Temperature functions of the material properties were considered with respect to extensive dependencies of the mechanical behaviour of polymers.

Keywords: laser cutting, polymer materials, transient-temperature field
\end{abstract}

V članku avtorji opisujejo nekonvencionalne tehnologije. Detajlno so raziskovali laserski snop in njegovo uporabo na različnih vrstah polimernih materialov. Avtorji so v članku osredotočeni na razpravo o prenosu toplote pri laserskem rezanju polimernih materialov. Že na majhnih razdaljah od roba rezanja se lahko zgodijo različne strukturne in kemične spremembe zaradi prenosa toplote na material. Nekateri vplivi so lahko znatni in so pomembni s stališča kakovosti izdelka. Z namenom, da bi določili širino vplivane cone so avtorji modelirali prehodno temperaturno polje, ki predstavlja porazdelitev temperature v bližini roba rezanja. Pri tem so upoštevali odvisnost materialnih lastnosti od temperature zaradi velikega vpliva temperature na mehansko obnašanje polimerov.

Ključne besede: lasersko rezanje, polimerni materiali, prehodno temperaturno polje

\section{INTRODUCTION}

The principle of this cutting method is the concentration of power - electromagnetic radiation of visible light - on a small surface of a product. The place of impact heats up considerably, exceeding the melting temperature of the machined material due to the transformation of the power of this visible radiation light into thermal power. The material melts and vaporises at the place of impact. The beam reflects the part absorbed; the part passes through the material after the impact of the beam on the material (Figure 1). Absorbed beams share the heating of the material. The amount of the reflected beam depends on the material reflectance. Absorption $A(\%)$ of luminous radiation implies the heating of the surface layer. Reflectance and absorption are complex events; the following relation shows their correlation in Equation (1):

$$
R+A=100 \%
$$

The absorption of luminous radiation and the following heat depend on the thermal conductivity of the material. The heat convection from the laser to the material is a complicated effect. Today, no true theory of the formulation of the thermal conductivity and temperature calculation exists because the heat transfer is rapid. The process propounded by Carslaw-Jaeger is used for formulating the heat transfer for a mobile source with a speed in $\mathrm{m} \mathrm{s}^{-1}$. The process presents a solution in the form of a partial differential equation for the heat convection from a source with the dimensions of a focused beam to the surface layer and in the material under specific marginal conditions. It follows from the simplified hypo-

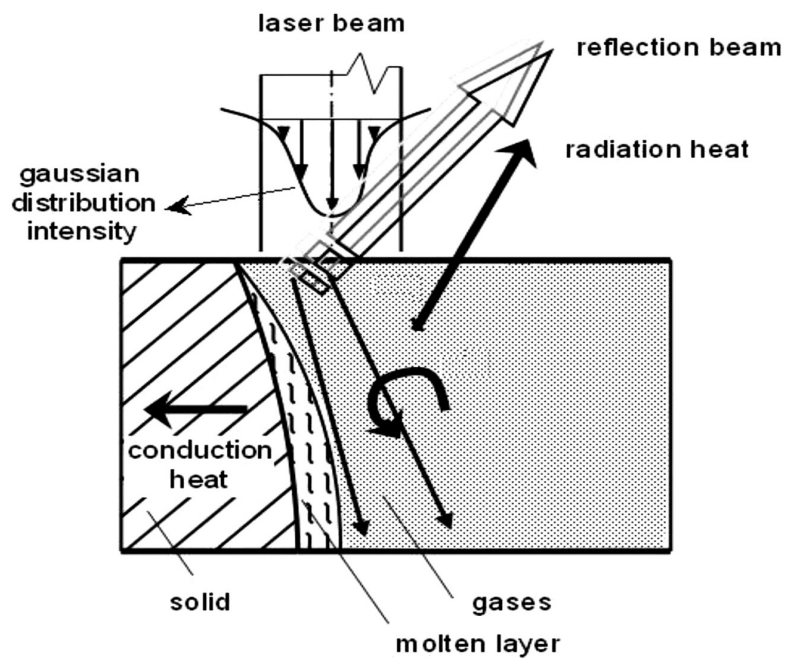

Figure 1: Laser-beam effect on the material 


\section{O. ŠUBA et al.: MODELLING OF A TRANSIENT-TEMPERATURE FIELD IN PLASTICS DURING LASER CUTTING}

thesis that the material of a product is isotropic and the heat transfer can be described with the equation of diffusion under definite marginal conditions in Equation (2):

$$
\frac{\partial T}{\partial t}=\alpha \Delta_{\mathrm{L}} T
$$

where $T$ is the absolute temperature $(\mathrm{K}), t$ is the time (s), $\Delta_{\mathrm{L}}$ is the specific elongation and $\alpha$ is the thermodiffusion given by the relation (Equation (3)):

$$
\alpha=\frac{k}{\rho \cdot c}
$$

where $k$ is the thermal-conductivity coefficient $\left(\mathrm{W} \mathrm{m} \mathrm{m}^{-1} \mathrm{~K}^{-1}\right), \rho$ is the density of the material $\left(\mathrm{kg} \mathrm{m}^{-3}\right)$ and $c$ is the specific heat $\left(\mathrm{J} \mathrm{kg}^{-1} \mathrm{~K}^{-1}\right)$ of solid material. $^{1-3}$

\section{EXPERIMENTAL PART}

For the laser cutting and subsequent simulation of the temperature field during the passage of the laser beam through the material, the following polymeric materials were chosen: polymethyl methacrylate (PMMA) as the representative of the amorphous polymer and polyethylene PE 1000 as the representative of the crystalline polymer. Commercial $\mathrm{CO}_{2}$ laser ILS $3 \mathrm{NM}$ was used for cutting of the chosen materials. For the experimental machining, the maximum value of power $(P=100 \mathrm{~W})$ and the minimum cutting speed $\left(f_{\max }=1524 \mathrm{~mm} \mathrm{~s}^{-1}\right)$ were chosen so that the interaction time between the laser and materials was as large as possible. The specimens were prepared, having dimensions of $30 \mathrm{~mm} \times 30$ $\mathrm{mm}$ and a thickness of $15 \mathrm{~mm}$. One laser cut was performed in the middle of each material and the depth of cut was evaluated. The measured cutting depth for PMMA was $15 \mathrm{~mm}$ and the measured cutting depth for PE 1000 was $8 \mathrm{~mm}$ (Figure 2).

\section{RESULTS AND DISCUSSION}

The polymer wall is cooled down gradually in a certain section after the beam passes and, at the same time, the heat flux extends away from the point of cut to the internal-wall volumes. The thermal process in the non-

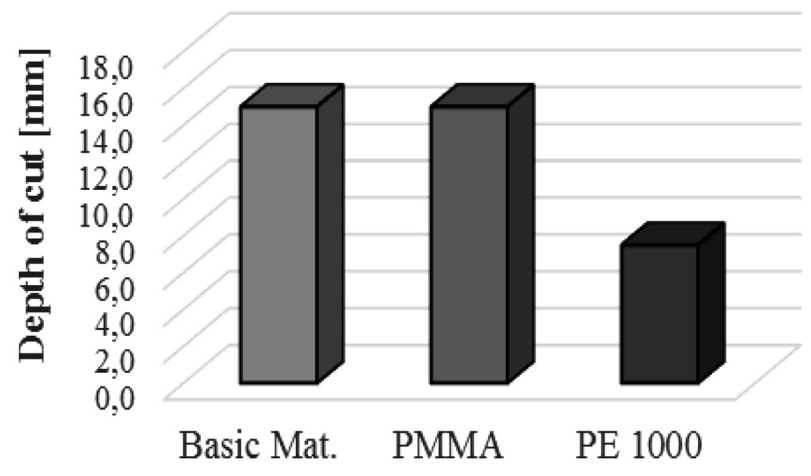

Figure 2: Measured values of the depth of grooves

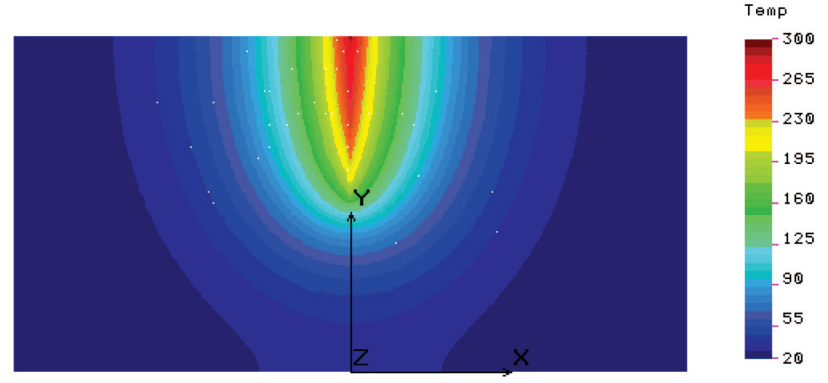

Figure 3: Temperature field in the crosscut of the wall (PE 1000)

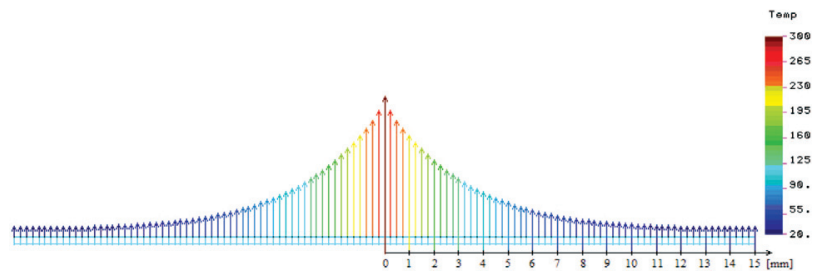

Figure 4: Profile of the temperature on the surface of the wall (PE 1000)

stationary, transient mode is described by the FourierKirchhoff differential equation, as mentioned above. Due to their specific values of the thermal-conductivity coefficient, in the case of sudden local heating, the thermoplastics keep their significant temperature differences in the heating area for a relatively long time. A particular problem is the fact that the thermoplastics exhibit significant physical, temperature dependencies. Consequently, the solution with constant material parameters is not valid and the physical characteristics have to be entered, as a function of temperature, in the temperature curves. When solving the problem, we considered the fact that a certain amount of energy of the laser beam is realised as a certain value of the heat flux

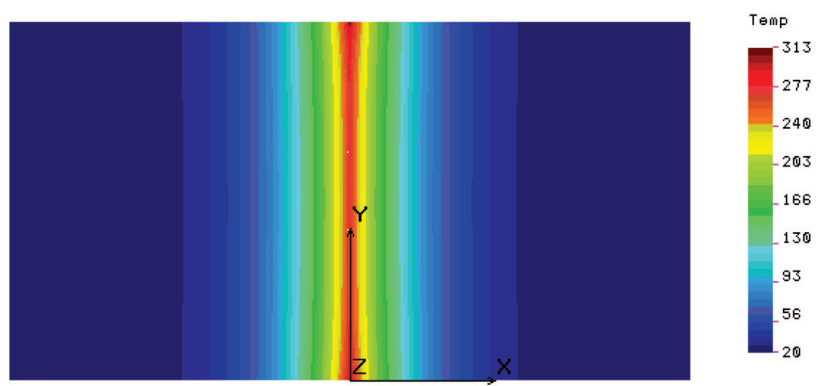

Figure 5: Temperature field in the crosscut of the wall (PMMA)

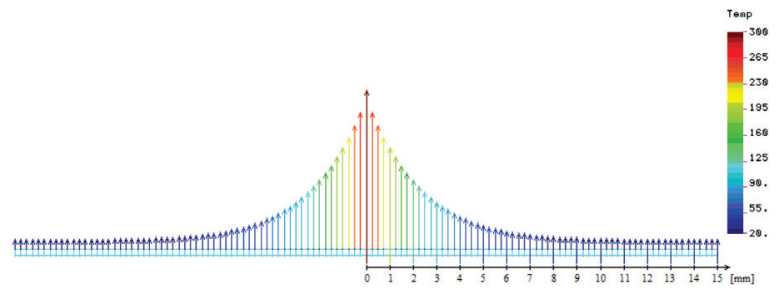

Figure 6: Profile of the temperature on the surface of the wall (PMMA) 


\section{O. ŠUBA et al.: MODELLING OF A TRANSIENT-TEMPERATURE FIELD IN PLASTICS DURING LASER CUTTING}

entering the surface of the remaining, solid part of the polymer at the cutting point. The rigid part is limited by the cracking temperature. By repeatedly changing the entered heat-flow value and following the analysis of the temperature field, the maximum temperature in the sectional area was adjusted to the above cracking temperature. ${ }^{4,5}$ The obtained results are shown in the following figures. The temperature field in the crosscut of the wall used for both polymeric materials can be seen in Figures 3 and 5 . Figures 4 and 6 show profiles of the temperature on the surface of the wall.

Table 1: Material properties (PE 1000)

\begin{tabular}{|c|l|c|}
\hline \multirow{3}{*}{ Material } & \multicolumn{1}{|c|}{ Material properties } & $\begin{array}{c}\text { Numerical } \\
\text { values }\end{array}$ \\
\hline \multirow{5}{*}{$\mathrm{PE}$} & Cracking temperature $\mathrm{T}_{\mathrm{p}}\left({ }^{\circ} \mathrm{C}\right)$ & $>300$ \\
\cline { 2 - 3 } & Density $\rho\left(\mathrm{kg} \cdot \mathrm{m}^{-3}\right)$ & 930 \\
\cline { 2 - 3 } & Specific heat $c_{\mathrm{p}}\left(\mathrm{J} \cdot \mathrm{kg}^{-1} \cdot \mathrm{K}^{-1}\right)$ & 1750 \\
\cline { 2 - 3 } & Thermal conductivity $\lambda\left(\mathrm{W} \cdot \mathrm{m}^{-1} \cdot \mathrm{K}^{-1}\right)$ & 0.4 \\
\cline { 2 - 3 } & Depth of cut $/$ thickness of mat. $(\mathrm{mm})$ & $6.3 / 15$ \\
\hline
\end{tabular}

Table 2: Material properties (PMMA)

\begin{tabular}{|l|l|c|}
\hline Material & \multicolumn{1}{|c|}{ Material properties } & Values \\
\hline \multirow{5}{*}{ PMMA } & Cracking temperature $\mathrm{T}_{\mathrm{p}}\left({ }^{\circ} \mathrm{C}\right)$ & $>300$ \\
\cline { 2 - 3 } & Density $\rho\left(\mathrm{kg} \mathrm{m}^{-3}\right)$ & 1180 \\
\cline { 2 - 3 } & Specific heat $c_{\mathrm{p}}\left(\mathrm{J} \mathrm{kg}^{-1} \mathrm{~K}^{-1}\right)$ & 1465 \\
\cline { 2 - 3 } & Thermal conductivity $\lambda\left(\mathrm{W} \mathrm{m}^{-1} \mathrm{~K}^{-1}\right)$ & 0.2 \\
\cline { 2 - 3 } & $\begin{array}{l}\text { Depth of cut } / \text { thickness of the mat. } \\
\text { (mm) }\end{array}$ & $15 / 15$ \\
\hline
\end{tabular}

\section{CONCLUSIONS}

From the results of the experiment, it is evident that the "laser machinability" of various polymeric materials varies. It follows from the unlike physical properties of the materials, especially the specific heat and thermal conductivity, that it is also possible to consider the influence of different crystal-lattice layouts. Based on the performed simulations of the temperature field, it can be seen that the high-temperature region, which can cause structural changes in the material, is narrow compared to metals. The simulations show that the area, in which depolymerisation and degradation of various materials can occur, is very small and reaches the maximum depth of $0.7 \mathrm{~mm}$. High-temperature gradients induce a high residual stress in the vicinity of the cut. Due to the complex mechanical behaviour of the polymers, the temperature and time dependence of this behaviour generally remain in the product after the end of the technological process involving the residual stress, which partially relaxes within the time. The residual stress negatively affects the utility properties of the respective plastic product. Unlike the elastic strain, the residual stress cannot be quantified due to the complex behaviour of the polymers at higher temperatures. The resulting residual stress is the result of various aspects. These include, in addition to the technological causes (a non-uniform heat dissipation, high-temperature gradients) material aspects, especially the orientation of the macromolecular structure or the degree of crystallinity.

\section{REFERENCES}

${ }^{1}$ W. Ozgowicz, Numerical simulation of an equilibrium segregation of impurities on the grain boundaries of copper and its alloys, Mater. Tehnol., 51 (2017) 3, 363-372

${ }^{2}$ L. Sykorova, O. Suba, J. Knedlova, Laser micro-machining and temperature field simulation, Key Engineering Materials, 581 (2014), 322-325, doi:10.4028/www.scientific.net/KEM.581.112

${ }^{3}$ M. Kubišová, V. Pata, L. Sýkorová, Creating and Evaluating Replicas of Surfaces Machined by Laser Beam, MATEC Web Conf., 121 (2017). 03013, doi:10.1051/matecconf/201712103013

${ }^{4}$ L. Sýkorová, V. Pata, M. Kubišová, J. Knedlová, Effect of concentrated energy of laser beam on polymer material, MATEC Web Conf., 121 (2017), 03021, doi:10.1051/matecconf/ 201712103021

${ }^{5}$ V. Pata, L. Sýkorová, M. Kubišová, M. Malachova, Resolving problems of finding surface boundaries during laser machining, (2016), doi:10.4028/www.scientific.net/MSF.862.66

${ }^{6}$ L. Sýkorová, V. Pata, M. Kubišová, M. Malachova, The "laser machinability" of polymeric materials, (2016), doi:10.4028/ www.scientific.net/MSF.862.141 